\title{
Respiratory physiotherapic intervention in adult asthmatic patients: an integrative review of literature
}

\author{
Anny Karolainy Silva de Lima ${ }^{1}$; Erivaldo Gomes da Silva²; Bruna Rafaela Dornelas de Andrade \\ Lima Monteiro3 ; Sâmia Dayana Lemos de Lacerda ${ }^{4}$; Catarina Souza Ferreira Rattes Lima*5 \\ 1 Graduate Program in Neonatal and Pediatric Intensive Care; CEFFAP Group - Center for Training and Professional Improvement, Recife, \\ Pernambuco, Brazil. \\ 2 Graduate Program in Neonatal and Pediatric Intensive Physiotherapy; CEFFAP Group - Center for Training and Professional Improvement, \\ Recife, Pernambuco, Brazil. \\ 3 Professor of the Physiotherapy course at UNIFACOL - University Center FACOL Faculty Writer Osman Lins, Vitória de Santo Antão, \\ Pernambuco, Brazil. \\ 4 Professor of the Nursing course at UNIFACOL - University Center FACOL Faculty Writer Osman Lins, Vitória de Santo Antão, Pernambuco, \\ Brazil. \\ 5 Professor of the Physiotherapy course at UNIFACOL - FACOL University Center
}

E-mail adresses:, annykarolainy1@gmail.com (Anny Karolainy Silva de Lima), erivaldo-gs@hotmail.com (Erivaldo Gomes da Silva), brunadornelasmonteiro@gmail.com (Bruna Rafaela Dornelas de Andrade Lima Monteiro), samia.lacerda@ufpe.br (Samia Dayana Lemos de Lacerda), catarina_rattes@hotmail.com (Catarina Souza Ferreira Rattes Lima)

${ }^{*}$ Corresponding author

\section{To cite this article:}

Lima, A.K.S.; Silva, E.G.; Monteiro, B.R.D.A.L.; Lacerda, S.D.L.; Lima, C.S.F.R. Respiratory physiotherapic intervention in adult asthmatic patients: an integrative review of literature. International Journal of Sciences. Vol. 2, No. 1, 2021, pp. 46-50. ISSN 2763-5392.

Received: 06 29, 2021; Accepted: 06 30, 2021; Published: 07 15, 2021

\begin{abstract}
The aim of this study is to analyze the evidence on respiratory physiotherapy intervention in adult asthmatic patients. Through an integrative literature review in medline/pubmed, LILACS and PEDro databases, studies without language restriction, published between 2009 and 2021. Those who used interventions in children and the elderly were excluded, as well as literature review studies, book chapters, dissertations and theses. After the search of the articles in the aforementioned databases, a total of 969 articles were found. When applying the eligibility criteria, 08 articles were selected to make up the present study. In view of the above, it can be affirmed that there is evidence that supports the importance of respiratory interventions in adult patients with asthma. Breathing exercises can provide short/long-term benefits, which are important for better disease control and quality of life. Education programs with asthma patients are also effective, because the broad knowledge of the disease, as well as the guidelines, interfere in the reduction of morbidity and a better quality of life.
\end{abstract}

Keywords: Asthma. Breathing Exercises. Rehabilitation.

\section{Introduction}

Asthma is considered a syndrome of recurrent respiratory symptoms caused by several factors such as viral respiratory infection, environmental allergens, climate change and pollution (REDDEL, 2015). Worldwide, about 300 million individuals of all ages have this disease (BATEMAN, 2008; BOUSQUET, 2010; BRIGHTLING, 2012). In Brazil, the prevalence is approximately $11 \%$ of the population (FREITAS; DA SILVA; DE CARVALHO et.al., 2015).
Characterized by chronic inflammation of the airways with structural and functional changes, asthma causes bronchial hyperresponsiveness and airway obstruction, causing periodic episodes of wheezing, feeling of chest tightening, dyspnea, and cough, along with marked events of worsening of symptoms, in what is known as exacerbations. Such symptoms may reverse spontaneously or to treatment (ZHANG; KÖHL, 2010; BRIGHTLING et al., 2012; BATEMAN et al., 2008).

Clinical manifestations are mainly triggered by exposure to allergenic or irritating factors. However, there are adjuvant factors that can trigger them, such as respiratory 
infection and physical exercise (FREITAS; DA SILVA; DE CARVALHO et.al., 2015).

These are risk factors associated with asthma: being male, being born with low birth weight, having viral respiratory infection early in life, having a family history of allergic diseases, being a smoker, sensitizing to environmental allergens, fungal products and endotoxins (SLY, 2011).

Currently, it is known about the variability of clinical, biological and functional characteristics of asthmatics, which led to the concept of phenotypes, that is, subgroups of patients with remarkable and common characteristics resulting from the interaction between genotypes and the environment (WENZEL, 2012; FAJT; WENZEL, 2014). Some of the phenotypes described are: asthma and allergies, asthma and fungal hypersensitivity, asthma and chronic obstructive pulmonary disease, asthma and obesity, asthma and aspirin intolerance, and asthma in the elderly and exercise-induced bronchospasm. Such phenotypes may in the future influence the particularized treatment of the disease (GUILLEMINAULT et al., 2017).

The diagnosis of asthma is clinical, that is, it is based on anamnesis and physical and complementary examinations to obtain it (TARASIDIS; WILSON, 2015). Spirometry can aid in the diagnosis, which is a pulmonary capacity test in order to evaluate the volume and airflow in the airways during the respiratory cycle, besides showing the worsening of airflow obstruction and monitoring the changes resulting from treatment (AVERAME, 2009; GINA, 2015). The diagnosis is not only proven by the finding of airflow limitation, but especially by symptoms partially or completely reversed after inhalation of the short-action bronchodilator (MILLER, 2005).

After the diagnosis of asthma, immediate treatment is essential in order to reduce the risks of exacerbation (GINA, 2015). It can be pharmacological, non-pharmacological, or include both approaches (LOUGHEED, 2012). As asthmatic individuals have mild to moderate disease, it is easily controlled with the bronchodilator for rapid action and inhaled corticosteroids for long-term control (ASPAR; ALMEIDA; NUNES, 2006). Regardless of the severity or age group of the patient, it is indispensable to be adhering to treatment for its control (BOURDIN et al., 2012).

It is necessary the correct use of the inlets, because otherwise, there is a therapeutic failure making it difficult to control the pathology. Thus, the importance of instruction by health professionals on the technique of using inhalators devices stands out (OLIVEIRA et al., 2014; PRICE et al., 2013; DE OLIVEIRA SANTOS et al., 2010).

Asthmatics need to be involved in an asthma education program, involving knowledge about pathophysiology to identify and avoid trigger factors, in addition to proficiency in inhaler use, to obtain a written treatment plan and to monitor themselves, as well as to return to the doctor regularly (GINA, 2015).

The physiotherapeutic intervention stands out as a nonpharmacological treatment and should be established when the patient is being followed by the doctor regularly and using the appropriate medication (BOTT et al., 2009). Among the main exercises that respiratory physiotherapy allows stand out: respiratory exercises, bronchial hygiene, respiratory muscle training and pulmonary rehabilitation, which are used specifically from the clinical picture of each patient (DE CORDOBA LANZA; DAL CORSO 2017).

In view of the above, the aim of the study is to analyze the evidence about respiratory physiotherapy intervention in adult asthmatic patients.

\section{Methodology}

The present work is an integrative review of the literature. As eligibility criteria, the inclusion criteria were established: publarticles published from 2009 to 2021, without language restriction, which described respiratory physiotherapy interventions in adult asthmatic patients. The excluded studies were those that used interventions in children, the elderly and pregnant women, as well as literature review studies, book chapters, dissertations and theses.

For the selection of articles, a search was conducted in the following electronic databases: Medical Literature Analysis and Retrieval System Online (Medline/Pubmed), Latin American and Caribbean Literature in Health Sciences (LILACS) and Physiotherapy Evidence Database (PEDro), using the keywords: "Asthma"; "Respiratory Physiotherapy"; "Chest Physiotherapy"; "Breathing Exercises" (TABLE 1). The Boolean descriptor "AND" was the only one applied associating the terms mentioned.

Table 1.Descriptors used to search the articles.

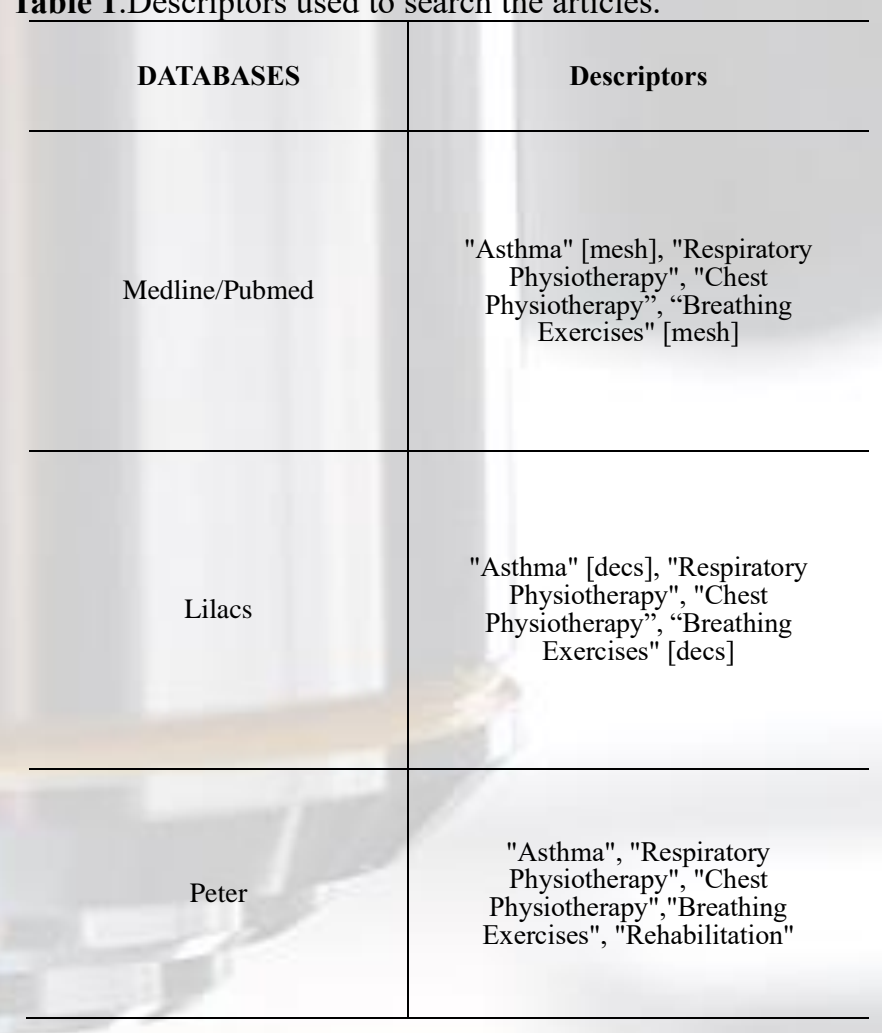

Source: Author (2021)

\section{Results and Discussions}


After searching the articles in the above-mentioned databases, a total of 969 articles were found, 874 from medline/pubmed database, 19 from lilacs database and 76 from PEDro database. When applying the previously established eligibility criteria, 28 articles were pre-selected, being removed 20 because they were in duplicate, resulting in 8 articles to make up the present study. (FIGURE 1).

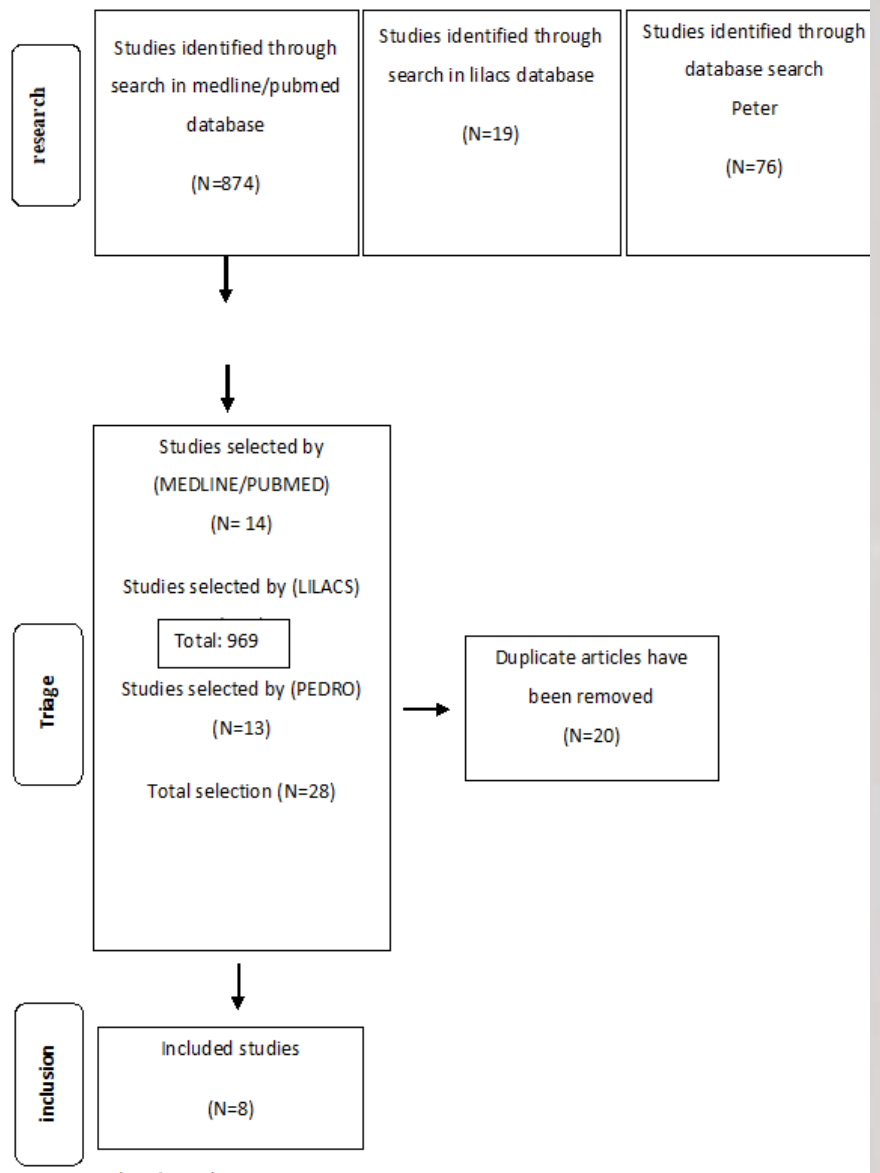

Figure 1. Flowchart of the selection of studies included in the literature review.

Table 2. Studies selected by the integrative literature review.

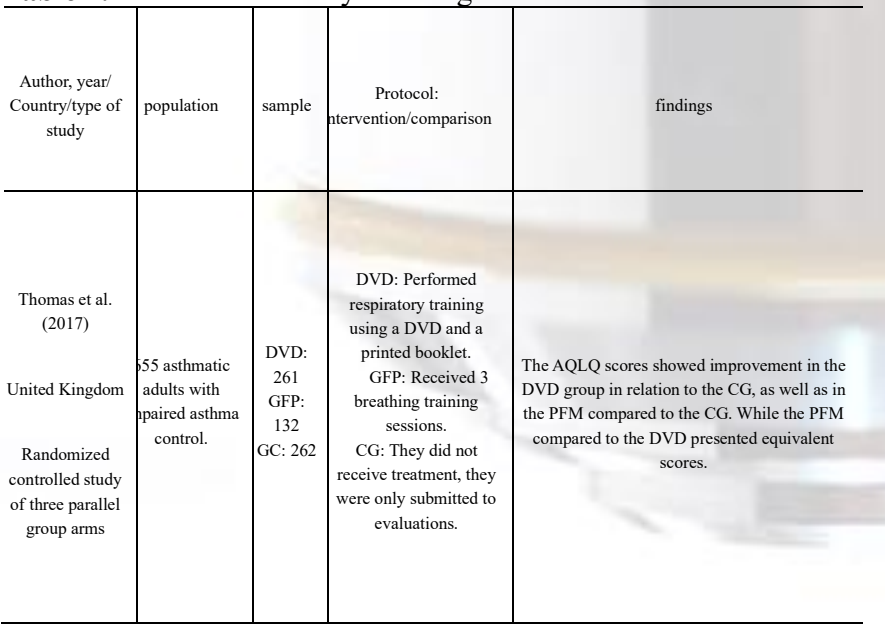

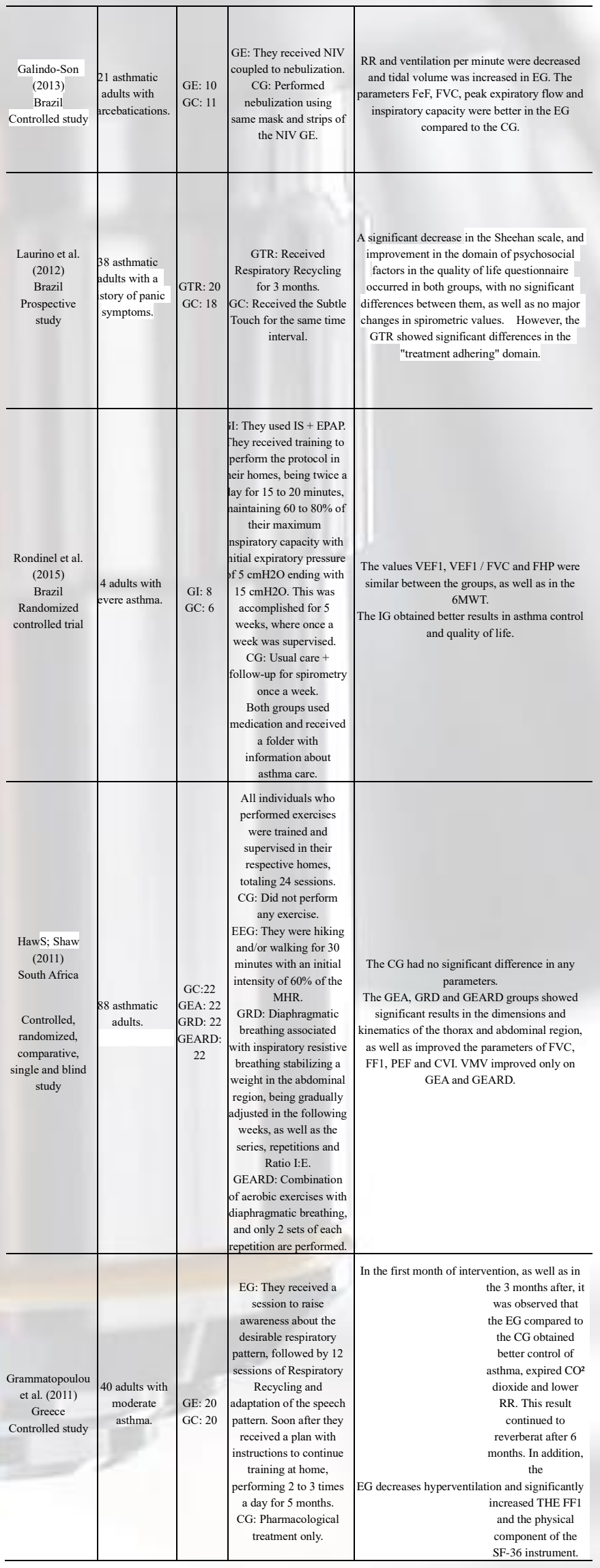


4 Lima, A.K.S.; Silva, E.G.; Monteiro, B.R.D.A.L.; Lacerda, S.D.L.; Lima, C.S.F.R. Respiratory physiotherapic intervention in adult asthmatic patients: an integrative review of literature...

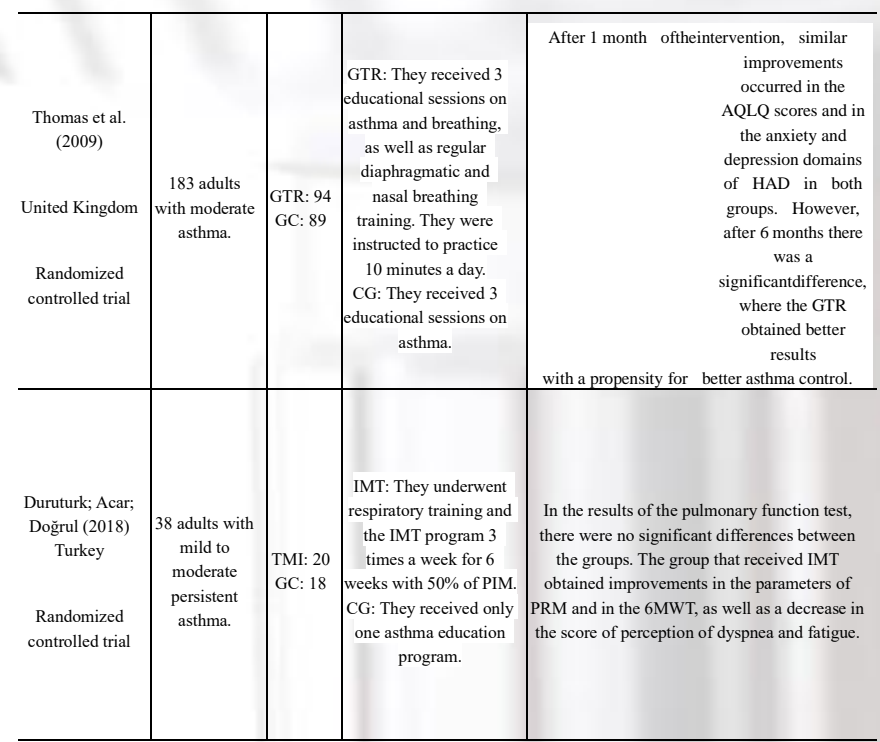

Legend: DVD: Versatile Digital Disc; PFM :Face-to-face Physiotherapy Group; GC: Control Group; AQLQ: Asthma Quality of Life Questionnaire; GTR: Respiratory Training Group; GI: Intervention Group; IS: Volumetric Incentive Spirometry; EPAP: Positive Expiratory Pressure in the Airways; VEF1: Forced Expiratory Volume in the First Spirometry; EPAP: Positive Expiratory Pressure in the Airways; VEF1: Forced Expiratory Volume in the First
Second; FVC: Forced Vital Capacity; EFS: Forced Expiratory Flow; TC6: 6-Minute Walk Test; ACQ: Asthma Control Questionnaire; GEA: Aerobic Exercise Group; GRD: Diaphragmatic Breathing Group; GEARD: Aerobic Exercise and Diaphragmatic Breathing Group; FCM: Maximum Heart Rate; I:E: Inspiration and Expiration; PEF: Peak Expiratory Flow; $\quad$ CVI: Vital Inspiratory Capacity; VMV: Maximum Voluntary Ventilation; GE: Experimental Group; SF-36: Inventory for Quality of Life Assessment; $\mathbf{C O}^{2}$ : Carbon dioxide; FR: Respiratory Rate; GTMI: Inspiratory Muscle Training Group; $\quad$ PIM: Maximal Inspiratotic Pressure; HAD: Anxiety and Depression Scale; IMT: Inspiratory Muscle Training; PRM: Maximum Respiratory Pressure; TC6: 6-minute walk test.

\section{Source: Author (2021)}

Thomas et al. (2017), studied the effects of self-guided respiratory training through a DVD and an explanatory booklet comparing with the same proposal of face-to-face treatment with a physiotherapist and with individuals who did not perform any type of intervention. They observed that the groups that performed interventions presented good results compared to those who did not, as well as there were no significant differences in the performance of face-to-face or self-guided respiratory training.

According to the results of the Galindo-Filho study (2013), the use of NIV associated with nebulization during asthma exacerbation improves respiratory parameters and causes clinical improvement in pulmonary function.

In another study conducted with adult asthmatics, the performance of Respiratory Recycling was analyzed compared to the Subtle Touch program in the improvement of asthma symptoms, degree of anxiety, panic disorder and quality of life. After the interventions, they observed that those who were treated with respiratory training presented improved asthma control and quality of life, as well as decreased panic and anxiety symptoms, when compared to the group that received the Sutil Touch program (LAURINO et al., 2012).

Other researchers conducted a study to evaluate the effects of the use of incentive spirometry associated with EPAP on increased tolerance to exercise, lung function and quality of life in patients with severe asthma. The results favored the use of coupled devices for better asthma control and quality of life (RONDINEL et al., 2015). Through his analysis, Shaw; Shaw (2011) compared the effects of aerobic exercise with diaphragmatic inspiratory resistive breathing and the combination of the two interventions in pulmonary function and dimensions and kinematics of the thorax and abdomen of asthmatics. The results showed that all interventions showed good improvements in the aforementioned criteria, but the participants belonging to the group who received both interventions obtained superior adaptations to the other groups.
Another study evaluated the effects of Respiratory Recycling on asthma control and physiological indices over time. The results showed that the technique provided not only asthma control and better physiological indices, but also higher quality of life for participants, who had six months after the interventions (GRAMMATOPOULOU et al., 2011).

Also, in order to demonstrate the importance of respiratory training, a study conducted with asthmatic people showed that both the group that received the intervention and the group that received the asthma education program had similar Scores of the AQLQ after one month. However, six months later there were significant differences between the groups, favoringthe group that performed respiratory training in the areas of anxiety and depression with a tendency to better asthma control (Thomas etal., 2009).

Duruturk; Acar; Doğrul (2018) investigated the results of inspiratory muscle training in asthmatic individuals compared to the asthma education program in respiratory muscle strength, fatigue, dyspnea, exercise capacity, daily life activity and quality of life. All aspects evaluated improved for the group that performed the intervention, except in the pulmonary function test, because it did not present significant differences between the groups.

\section{Conclusions}

In view of what was presented in this review article, it can be affirmed that there is evidence that supports the importance of respiratory interventions in adult patients with asthma. Breathing exercises can provide short/long-term benefits, which are indispensable for better disease control and quality of life. In cases of acute asthmatic exarcebatiations, NIV is shown to be evident to be essential in these situations.

Asthma education programs are effective, because the broad knowledge of the disease as well as the guidelines, interfere in the reduction of morbidity and a better quality of life, being considered as one of the pillars of asthma treatment.

\section{References}

[1] AVERAME, G. et al. Office spirometry can improve the diagnosis of obstructive airway disease in primary care setting. Respir Med, v. 103, n.6, p.866-72, 2009.

[2] ASPAR, A.; ALMEIDA, M.M.; NUNES, C. Epidemiologia da asma grave. Rev Portug Imunoalergol, v. 14, n.1, p. 17-41, 2006.

[3] BATEMAN, E.D. et al. Global strategy for asthma management and prevention: GINA executive summary. European Respiratory Journal, v. 31, n.1, p. 143-78, 2008.

[4] BOURDIN, A. et al. Adherence in severe asthma. Clinical \& Experimental Allergy, v. 42, n. 11, p. 1566-1574, 2012.

[5] BOUSQUET, J. et al. Uniform definition of asthma severity, control, and exacerbations: document presented for the World Health Organization Consultation on Severe Asthma. Journal of Allergy and Clinical Immunology, v.126, n.5, p. 926-938, 2010.

[6] BOTT, J. et al. Guidelines for the physiotherapy management of the adult, medical, spontaneously breathing patient. Thorax, v. 64 Suppl 1, p. i1-i51, 2009.

[7] BRIGHTLING, C.E. et al. Lung damage and airway remodelling in severe asthma. Clinical and Experimental Allergy, v.42, n.5, p.638-49, 2012.

[8] DE CORDOBA LANZA, F.; DAL CORSO, S. Fisioterapia no 
paciente com asma: intervenção baseada em evidências. Arq Asma Alerg Imunol, v. 1, n.1, p. 59-64, 2017.

[9] DE OLIVEIRA SANTOS, D. et al. Atenção farmacêutica ao portador de asma persistente: avaliação da aderência ao tratamento e da técnica de utilização dos medicamentos inalatórios. J Bras Pneumol, v. 36, n. 1, p. 14-22, 2010.

[10] DURUTURK, N.; ACAR, M.; DOĞRUL, M. I. Effect of inspiratory muscle training in the management of patients with asthma. Journal of cardiopulmonary rehabilitation and prevention, v. 38, n. 3, p. 198-203, 2018.

[11] FAJT, M.L.; WENZEL, S. E. Biologic therapy in asthma: entering the new age of personalized medicine. Journal of Asthma, v. 51, n. 7, p. 669-676, 2014.

[12] FREITAS, P.D.; DA SILVA, R.A.; DE CARVALHO, C.R.F. Efeitos do exercício físico no controle clínico da asma. Revista de Medicina, v. 94, n. 4. 2015. p. 246-255, 2015.

[13] GALINDO-FILHO, V. C. et al. Noninvasive ventilation coupled with nebulization during asthma crises: a randomized controlled trial. Respiratory care, v. 58, n. 2, p. 241-249, 2013.

[14] GUILLEMINAULT, L. et al. Personalised medicine in asthma: from curative to preventive medicine. European Respiratory Review, v. 26, n. 143, p. 160010, 2017.

[15] GINA - Global Initiative for Asthma. Global Strategy for Asthma Management and Prevention. National Institutes of Health, 2015. National Heart, Lung and Blood Institut of Health, Bethesda. Disponível em: http://www.ginasthma.org/. Acesso em: 30 Out. 2019.

[16] GRAMMATOPOUlOU, E. P. et al. The effect of physiotherapy-based breathing retraining on asthma control. Journal of Asthma, v. 48, n. 6, p. 593-601, 2011.

[17] LAURINO, R. A. et al. Respiratory rehabilitation: a physiotherapy approach to the control of asthma symptoms and anxiety. Clinics, v. 67, n. 11, p. 1291-1297, 2012.

[18] LOUGHEED, M.D. et al. Canadian Thoracic Society 2012 guideline update: diagnosis and management of asthma in preschoolers, children and adults. Canadian respiratory journal, v. 19, n. 2, p. 127-164, 2012.

[19] MILLER, M. R. ATS/ERS task force: standardisation of spirometry. Eur Respir J, v. 26, p. 319-338, 2005.

[20] OLIVEIRA, P.D. et al. Avaliação de técnicas de inalação empregadas por pacientes com doenças respiratórias no sul do Brasil: estudo de base populacional. Jornal Brasileiro de Pneumologia, v.40, n.5, p.513-20, 2014.

[21] PRICE, D. et al. Inhaler competence in asthma: common errors, barriers to use and recommended solutions. Respiratory medicine, v. 107, n. 1, p. 37-46, 2013.

[22] REDDEL, H.K. et al. A summary of the new GINA strategy: a roadmap to asthma control. European Respiratory Journal, v. 46, n. 3, p. 622-639, 2015.

[23] RONDINEL, T. Z. et al. Incentive spirometry combined with expiratory positive airway pressure improves asthma control and quality of life in asthma: a randomised controlled trial. Journal of Asthma, v. 52, n. 2, p. 220-226, 2015.

[24] SHAW, B. S.; SHAW, I. Pulmonary function and abdominal and thoracic kinematic changes following aerobic and inspiratory resistive diaphragmatic breathing training in asthmatics. Lung, v. 189, n. 2, p. 131-139, 2011.

[25] SLY, P.D. The early origins of asthma: who is really at risk?. Current opinion in allergy and clinical immunology, v. 11, n. 1 , p. 24-28, 2011.

[26] TARASIDIS, G.S.; WILSON, K. F. Diagnosis of asthma: clinical assessment. International forum of allergy \& rhinology, p. S23-S26, 2015.

[27] THOMAS, M. et al. A randomised controlled study of the effectiveness of breathing retraining exercises taught by a physiotherapist either by instructional DVD or in face-to-face sessions in the management of asthma in adults. Health Technol Assess, v. 21, p. 1-162, n.1, 2017.

[28] THOMAS, M. et al. Breathing exercises for asthma: a randomised controlled trial. Thorax, v. 64, n. 1, p. 55-61, 2009.

[29] WENZEL, S.E. Asthma phenotypes: the evolution from clinical to molecular approaches. Nature medicine, v. 18 , n. 5 , p. 716 , 2012.

[30] ZHANG, X.; KÖHL, J.A complex role for complement in allergic asthma. Expert review of clinical immunology, v. 6, n. 2, p. $269-277,2010$. 